\title{
Protein surface charge of trypsinogen changes its activation pattern
}

Karin Buettner ${ }^{1}$, Thomas Kreisig ${ }^{1}$, Norbert Sträter ${ }^{1}$ and Thole Zuchner ${ }^{1,2^{*}}$

\begin{abstract}
Background: Trypsinogen is the inactive precursor of trypsin, a serine protease that cleaves proteins and peptides after arginine and lysine residues. In this study, human trypsinogen was used as a model protein to study the influence of electrostatic forces on protein-protein interactions. Trypsinogen is active only after its eight-amino-acid-long activation peptide has been cleaved off by another protease, enteropeptidase. Trypsinogen can also be autoactivated without the involvement of enteropeptidase. This autoactivation process can occur if a trypsinogen molecule is activated by another trypsin molecule and therefore is based on a protein-protein interaction.

Results: Based on a rational protein design based on autoactivation-defective guinea pig trypsinogen, several amino acid residues, all located far away from the active site, were changed to modify the surface charge of human trypsinogen. The influence of the surface charge on the activation pattern of trypsinogen was investigated. The autoactivation properties of mutant trypsinogen were characterized in comparison to the recombinant wild-type enzyme. Surface-charged trypsinogen showed practically no autoactivation compared to the wild-type but could still be activated by enteropeptidase to the fully active trypsin. The kinetic parameters of surface-charged trypsinogen were comparable to the recombinant wild-type enzyme.

Conclusion: The variant with a modified surface charge compared to the wild-type enzyme showed a complete different activation pattern. Our study provides an example how directed modification of the protein surface charge can be utilized for the regulation of functional protein-protein interactions, as shown here for human trypsinogen.
\end{abstract}

Keywords: Protein design, Protein expression, Protein-interaction, Protein engineering, trypsin

\section{Background}

Protein-protein interactions are based on non-covalent interactions of amino acids on protein surfaces via van der Waals forces, hydrogen bridges, electrostatic interactions and hydrophobic effects. Other processes that can be influenced by electrostatic interactions include for example protein folding and protein stability, protein denaturation and solubilization or precipitation of proteins [1]. In addition, the binding of substrates by enzymes, the subsequent catalytic processes and also the formation of protein-protein complexes can be based on electrostatic interactions.

The human enzyme trypsinogen shows a distinct distribution of protein surface charges and may be an attractive model protein to study the influence of electrostatic forces

\footnotetext{
* Correspondence: Thole.Zuechner@octapharma.com

${ }^{1}$ Institute of Bioanalytical Chemistry, Center for Biotechnology and Biomedicine, Universität Leipzig, 04103 Leipzig, Germany

${ }^{2}$ Current address: Octapharma Biopharmaceuticals $\mathrm{GmbH}$, Im Neuenheimer Feld 590, Heidelberg 69120, Germany
}

\section{(O) BioMed Central}

on protein-protein interactions. The activation of trypsinogen by its natural activation enzyme, the serine protease enteropeptidase, is determined by a close interaction between the two proteases. Trypsinogen is the inactive precursor of trypsin (PRSS1, human cationic trypsinogen), which can cleave proteins and peptides after lysine and arginine residues and is activated by the membrane-bound enteropeptidase via cleavage of the $\mathrm{N}$-terminal activation peptide located on the trypsinogen surface. The resulting trypsin itself activates other pancreatic zymogens of the digestive pathway [2]. Besides the specific activation of trypsinogen by enteropeptidase it is well known that trypsinogen can show autoactivation [3].

This trypsinogen autoactivation process is mostly based on the fact that active trypsin can activate trypsinogen by cleaving off its activation peptide in a similar way as occurs with the activation enzyme enteropeptidase. Subsequently, the newly formed trypsin can then accelerate the 
activation of other trypsinogen molecules in a cascade reaction.

Several mutations that influence the autoactivation of human trypsinogen have been published and are discussed in the context of the development of pancreatitis $[4,5]$. A number of studies have investigated the influence of different mutations on the autoactivation process [6-8]. In these studies, autoactivation was initiated by addition of a small amount of trypsin. As the same amount and type of trypsin was used throughout these studies, this ensures that autoactivation was characterized in a comparable way.

Some studies [3,9] have also hypothesized that trypsinogen autoactivation may not require the presence of either active trypsin or active enteropeptidase, but that trypsinogen itself could have an inherent, though minimal, catalytic function and could therefore activate itself. However, physiological conditions of course include the possibility that trypsinogen activation could also occur to a minor extent through the non-specific cleavage by proteases other than trypsin or enteropeptidase. In addition, it may be experimentally challenging to exclude the presence of even the smallest amount of active protease in order to investigate this problem. We therefore decided to study the autoactivation process by adding a small defined amount of active trypsin to ensure comparability with published studies and congruent results.

Trypsinogen autoactivation as observed for the human enzyme differs from that observed in other organisms [10]. For example, trypsinogen from guinea pig is defective in autoactivation under conditions where human cationic and anionic trypsinogen rapidly autoactivate [8]. The reason for this different autoactivation behavior has not been clear until now. The guinea pig variant has a sequence identity of $75 \%$ with human cationic trypsinogen. However, when we compared the number of charged amino acids between human and guinea pig trypsinogen, we found a striking difference in the number of charged amino acids (26 vs. 42 in human cationic trypsinogen). More than this, when we looked at the position of these charged amino acids within the protein model, it turned out that a striking difference in the surface charge distribution between human and guinea pig wild-type trypsinogen can be observed (Figure 1a and b). Based on this observation, our aim was to study the influence of a modified protein surface charge of human trypsinogen on specific enzyme properties, and in particular on the autoactivation. Our hypothesis was, that the distinct distribution of surface charges could potentially influence the activation pattern of the enzyme. To study this in detail, we also had to consider that guinea pig trypsinogen contains a lysine at position 79 instead of the typical glutamine residue found in other mammalian trypsinogens. The functional role of this side chain is unclear, but the Glu79Lys mutation (E79K) in human cationic trypsinogen seems to be associated with chronic pancreatitis and also leads to a lower autoactivation compared to the wild type [11].

The rational optimization of surface charge-charge interactions has been described before, for example as a strategy to enhance protein stability [12]. The advantages of this method are that mutations on the protein surface are less likely to significantly affect the core structure and therefore the function of the protein [13]. One example is the generation of highly thermoresistant antibodies by increasing their surface charge [14]. The mutation of surface residues to charged amino acids is also known to decrease protein aggregation. Previously, the method of supercharging was demonstrated to increase the resistance of

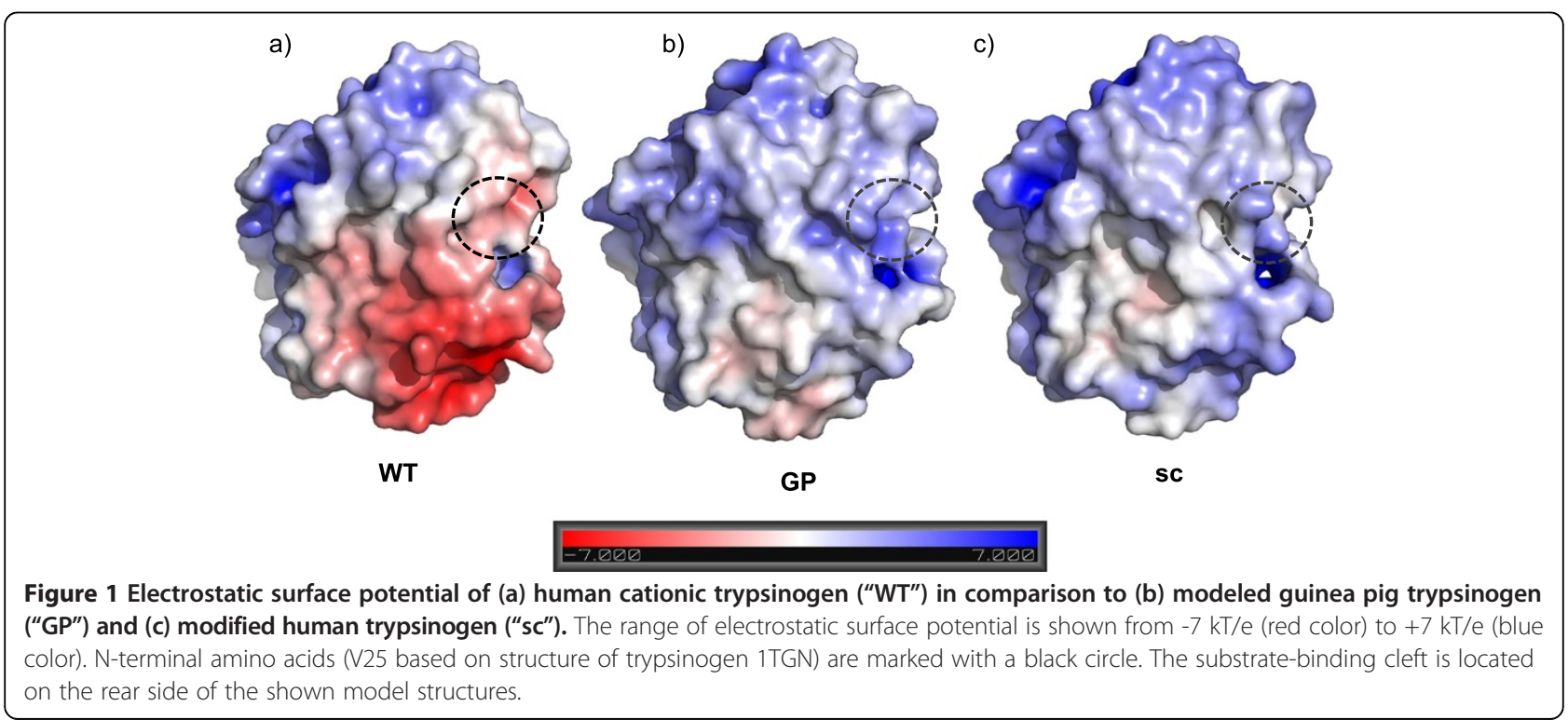


green fluorescent protein (GFP) to temperature-induced aggregation $[15,16]$ to increase the solubility of a human enteropeptidase by more than 100-fold [17]. These studies reported the influence of protein surface charge on rather general protein properties such as solubility, aggregation properties and thermoresistance.

In this paper, we describe the modification of human trypsinogen by the exchange of several amino acid residues on the protein surface and its effect on specific properties of the protein such as the protein-protein interaction behavior of trypsinogen with enteropeptidase and active trypsin.

\section{Results}

\section{Rational protein design}

In this work, we examined the influence of the protein surface charge on protein-protein interactions of the serine protease human trypsinogen. Trypsinogen is an interesting model protein because it can be activated both by trypsin and by enteropeptidase. The resulting active trypsin can then contribute to the further activation of other trypsinogen molecules. As a result of the increasing amounts of active trypsin, a cascade reaction of autoactivation is observed. One interesting trypsinogen variant that shows nearly no autoactivation is the trypsinogen from guinea pig [8]. After we had done a sequence comparison between guinea pig and human cationic trypsinogen, several residues could be identified that are different in charge (Figure 2).

Interestingly, when we looked at the spatial distribution of these charged amino acids in the 3D structure of the protein, these charged amino acids are mostly located on the enzyme surface and distributed in a very distinct way (Figure 1). Inspired by this finding, we created a human trypsinogen mutant in which we tried to include a similar surface charge distribution as found by us for the guinea pig version. Although this kind of influence of a proteins surface charge on its activation pattern has never been described before, we aimed to examine its influence on the activation pattern of human trypsinogen.

After the amino acid sequence alignment of both variants, ten residues were identified that could lead to a different protein surface potential for trypsinogen. To prevent the undesirable loss of enzyme activity or specificity

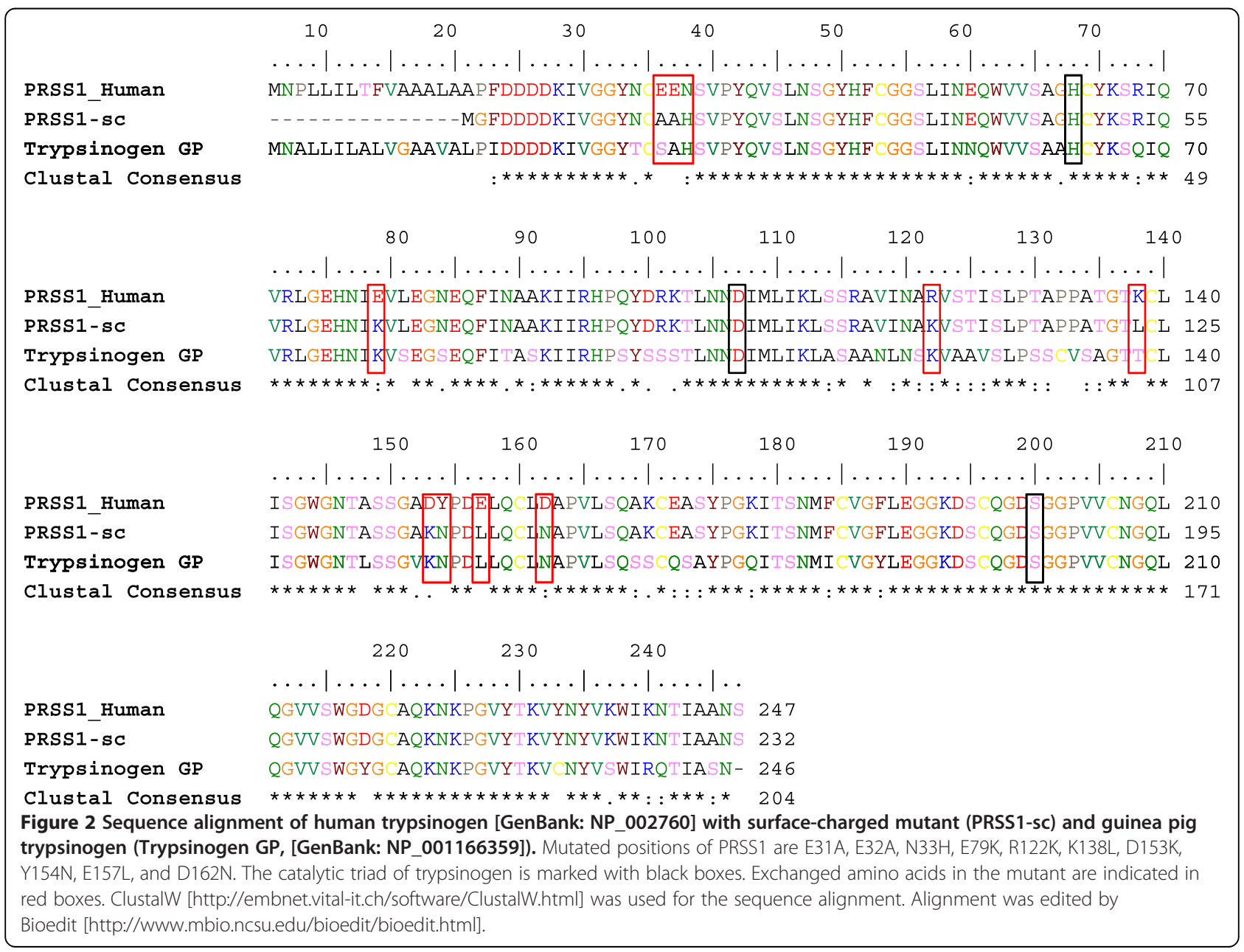


by mutations in the generated human trypsinogen variant, it was necessary to engineer the protein in such a way as to minimize the influence on the active center of the enzyme. Thus, mutated positions were checked to be on the surface of the protein and, in particular, to be distant from the activation sequence of the enzyme (distance $>10 \AA$ ). The mutations were then performed in a way that the predicted electrostatic potential of the variant matched that of guinea pig trypsinogen.

In detail, the following ten mutations were introduced: E31A, E32A, N33H, E79K, R122K, K138L, D153K, Y154N, E157L, and D162N. We decided not to mutate position 138 like in the sequence of guinea pig trypsinogen, which has a threonine at this position to prevent posttranslational modification of $\mathrm{OH}$-groups. The same consideration applied to position 31 and 154 [18,19].

In total, the trypsinogen sc variant has 16 negatively charged residues compared to the 22 in the wild-type enzyme and 21 positively charged residues compared to the 20 in the wild type. Thus, the net charge was increased from -2 to +5 . Several mutations are known to potentially influence the autoactivation and autolysis of human trypsinogen like E79K and R122H [11,20]. Furthermore, the position R122 has the potential to influence the autolysis of the protein. It was therefore necessary to examine the influence of these positions on the human trypsinogen so as to allow a clear conclusion about the influence of the protein surface charge as compared to the effect of these point mutations. The effect of these mutations will be discussed later in this study.

\section{Autoactivation of trypsinogen at $\mathrm{pH} 8$}

The autoactivation of human wild-type trypsinogen and the surface-charged variant (PRSS1-sc) was investigated at $\mathrm{pH} 8$ and $37^{\circ} \mathrm{C}$ for several hours. To initiate the autoactivation and in accordance with several other studies [6-8], $10 \mathrm{nmol} / \mathrm{L}$ trypsin was added to $2 \mu \mathrm{mol} / \mathrm{L}$ trypsinogen. The time-course of the autoactivation was quantified by determination of the trypsin activity (Figure 3).

In agreement with previous studies, the human wildtype enzyme showed a high autoactivation [7]. This high autoactivation rate results in the complete activation of trypsinogen within $80 \mathrm{~min}$. PRSS1-WT exhibits an activation rate constant of $30.9 \mathrm{nmol} / \mathrm{L} / \mathrm{min}$ for activation of trypsinogen by trypsin. In contrast to this, the surfacecharged PRSS1-sc variant showed nearly no detectable activity during the whole incubation time under the same conditions. This means, that the surface-charged trypsinogen variant shows a dramatically reduced activation rate when using trypsin as the activating enzyme. An activation rate constant of $0.00545 \mathrm{nmol} / \mathrm{L} / \mathrm{min}$, which is more than 5000 times slower than for the wildtype enzyme, was determined for the PRSS1-sc mutant. These results were also confirmed by SDS-PAGE analysis (Figure 4).

In SDS-PAGE, the band corresponding to human wild-type trypsinogen is detectable only in the 20 and 40 min samples. Even after 40 min the lower molecular weight band corresponding to the active trypsin molecule is the dominant species. In contrast, the surface-charged

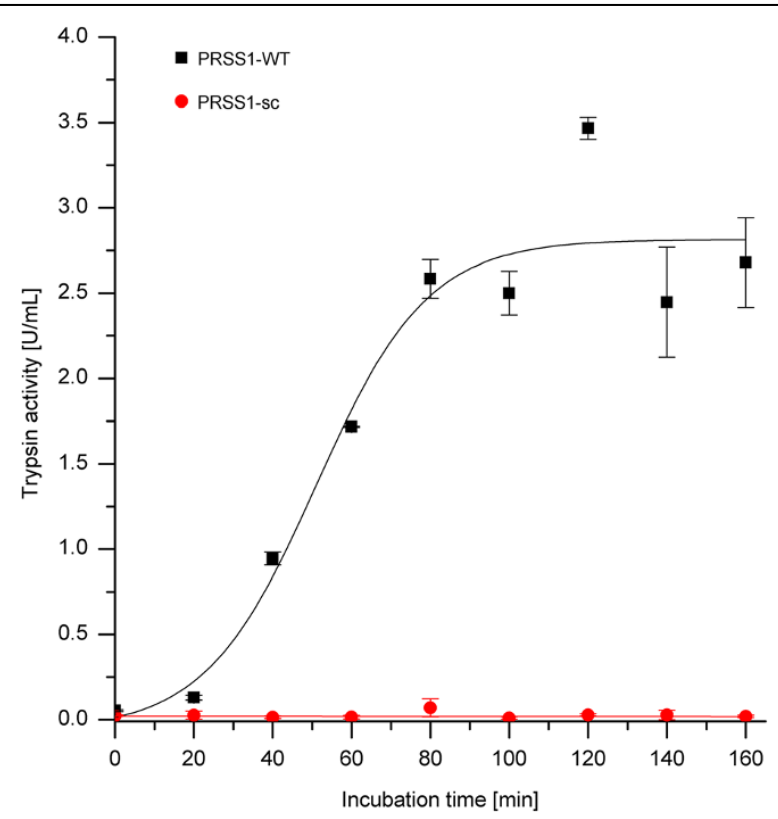

Figure 3 Autoactivation of trypsinogen at pH 8. Trypsinogen autoactivation was measured in $100 \mathrm{mmol} / \mathrm{L}$ Tris- $\mathrm{HCl} \mathrm{pH} 8,1 \mathrm{mmol} / \mathrm{L} \mathrm{CaCl}$ at $37^{\circ} \mathrm{C}$ with $2 \mu \mathrm{mol} / \mathrm{L}$ trypsinogen and $10 \mathrm{nmol} / \mathrm{L}$ trypsin as an initial starting concentration. Trypsin activity was determined with Cbz-GPR-pNA as substrate. 
trypsinogen showed no detectable shift in the molecular weight and also no degradation of the enzyme. This confirms the finding of the activity measurement (Figure 3), i.e., that nearly no autoactivation occurs in the surfacecharged variant.

The autoactivation of wild-type and surface-charged trypsinogen was also investigated at higher ionic strength to further confirm our hypothesis that autoactivation is influenced by the surface charge of the trypsinogen molecule and therefore the binding between the molecules. We could observe a decreased autoactivation of the wildtype trypsinogen compared to the experiment without the addition of salt (Figure 5).

The PRSS1-sc mutant contains the mutation E79K, besides the other mutations described above. The E79K mutation has previously been described to cause a decreased autoactivation [11]. Therefore, we also generated the point mutant PRSS1-E79K and investigated its autoactivation properties in the same way as for wild-type trypsinogen. Under the conditions used in this study, the E79K mutant showed an autoactivation that was comparable to that of the wild-type trypsinogen (Additional file 1: Figure S1). This finding seemingly contradicts the previously published result [11] where this mutant did not show autoactivation. However, in the study published by Teich et al., no trypsin was added to initiate the autoactivation and the activation behavior was not measured for a prolonged time. We additionally determin the autoactivation behavior of wild-type trypsinogen and PRSS1-E79K with the addition of a lower amount of trypsin $(1 \mathrm{nmol} / \mathrm{L})$. We could confirm that autoactivation mechanism is influenced by the amount of added trypsin. The addition of a lower amount of trypsin led to a decreased autoactivation for wild-type trypsinogen and also for mutant PRSS1-E79K (Additional file 1: Figure S1). We can therefore conclude that the E79K mutation did not significantly contribute to the observed decreased autoactivation in PRSS1-sc under the conditions used in this study.

\section{Activation with enteropeptidase}

In its physiological setting, trypsinogen is activated by enteropeptidase. We therefore examined the activation behavior of the human wild-type and the surface-charged trypsinogen by human enteropeptidase to see if the surface-charged variant could be activated in a normal manner. The characterization of the trypsin activity after enteropeptidase activation showed that the surfacecharged trypsinogen could be activated to normal wildtype levels after 100 to 120 min (Figure 6). In comparison, the wild-type trypsinogen was already completely active after $40 \mathrm{~min}$. The activity of surface charged trypsinogen increases up to $3.5 \mathrm{U} / \mathrm{mL}$ compared to wild-type trypsinogen with $2.5 \mathrm{U} / \mathrm{mL}$ activity. These differences are based on different specific activities of the variants (PRSS1-sc 69 $\mathrm{U} / \mathrm{mg}$ and PRSS1-WT $54.6 \mathrm{U} / \mathrm{mg}$ ). The detailed kinetic parameters of wild-type and surface charged trypsinogen can be found in Table 1. The surface-charged and wildtype trypsinogen were incubated with enteropeptidase over 4 hours at $37^{\circ} \mathrm{C}$ without showing a decreasing activity, indicating that both trypsinogen mutants are in a stable conformation.

The activation rate constant for the activation of PRSS1-WT by enteropeptidase was $86.4 \mathrm{nmol} / \mathrm{L} / \mathrm{min}$, which is slightly higher (a factor of 6.5) compared to the activation rate constant for PRSS1-sc $(13.3 \mathrm{nmol} / \mathrm{L} / \mathrm{min})$. This means that the activation rate of mutant PRSS1-sc is slowed down by a factor of more than 5000 when trypsin is used as the activating enzyme, whereas the same mutant can still be activated to normal levels when enteropeptidase is used as the activating enzyme, albeit at a 6.5 -fold slower rate.

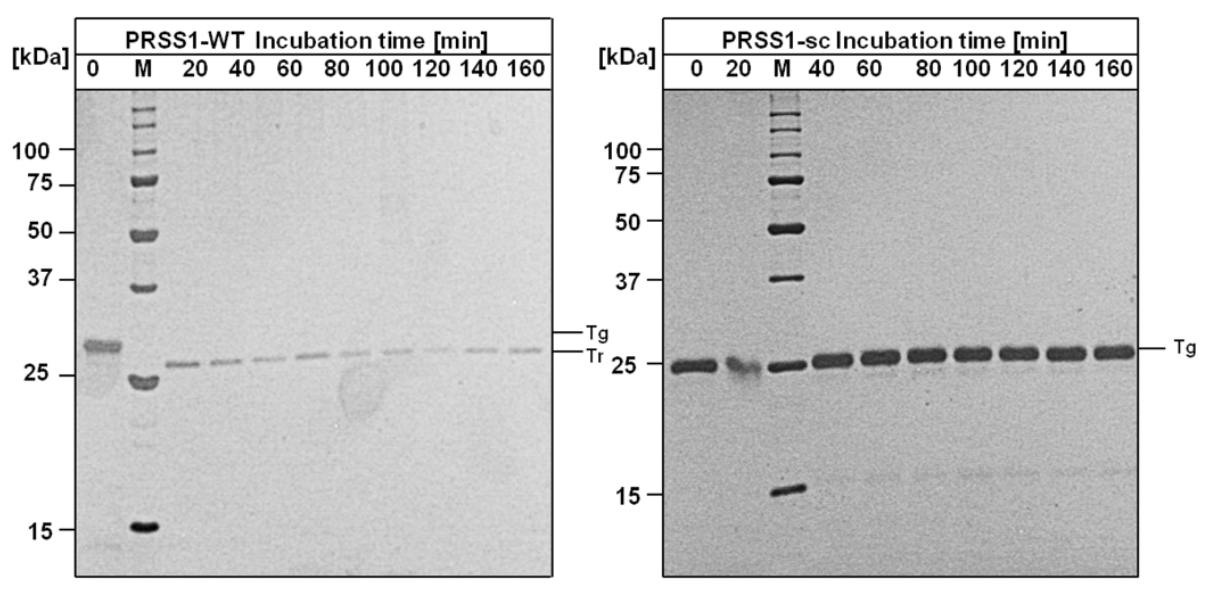

Figure 4 SDS-PAGE analysis of autoactivation of human trypsinogen. The samples were analyzed on a 15\% reducing SDS-PAGE gel using silver staining. Reactions were terminated by adding SDS-PAGE sample buffer followed by an immediate denaturation step for 5 min at $95^{\circ} \mathrm{C}$ ( $\mathrm{Tg}=$ trypsinogen; $\mathrm{Tr}=$ trypsin). 


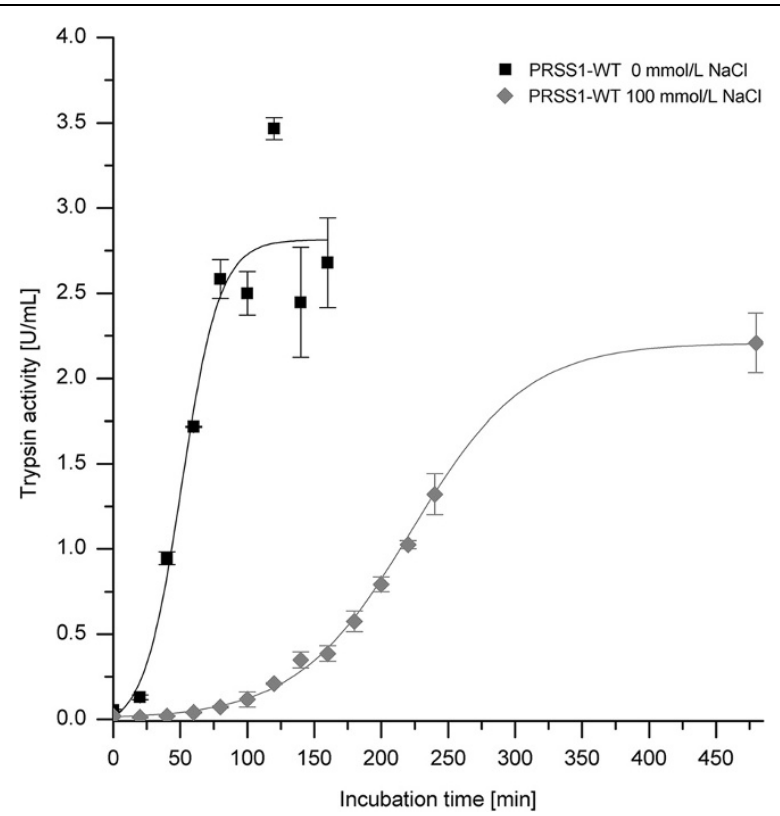

Figure $\mathbf{5}$ Autoactivation of trypsinogen at $\mathbf{p H} \mathbf{8}$ and different salt concentrations. Trypsinogen autoactivation was measured in $100 \mathrm{mmol} / \mathrm{L}$ Tris- $\mathrm{HCl} \mathrm{pH} 8,1 \mathrm{mmol} / \mathrm{L} \mathrm{CaCl} 2$ and $100 \mathrm{mmol} / \mathrm{L} \mathrm{NaCl}$ at $37^{\circ} \mathrm{C}$ with $2 \mu \mathrm{mol} / \mathrm{L}$ trypsinogen and $10 \mathrm{nmol} / \mathrm{L}$ trypsin as an initial starting concentration. Trypsin activity was determined with Cbz-GPR-pNA as substrate.

The course of this human enteropeptidase-mediated activation behavior of the surface-charged trypsinogen vs. wild-type trypsinogen was also examined via SDSPAGE analysis (Figure 7). The results showed that it is possible to activate the surface-charged mutant to a full extent by using human enteropeptidase.
Two degradation bands are visible after activation. In previous studies, it was shown that these degradation bands are connected to the cleavage of the Arg122-Val123 peptide bond [21]. Arg122 is exchanged to a lysine residue in the surface-charged trypsinogen, which indicates that the Lys122-Val123 bond can also be cleaved by trypsin.

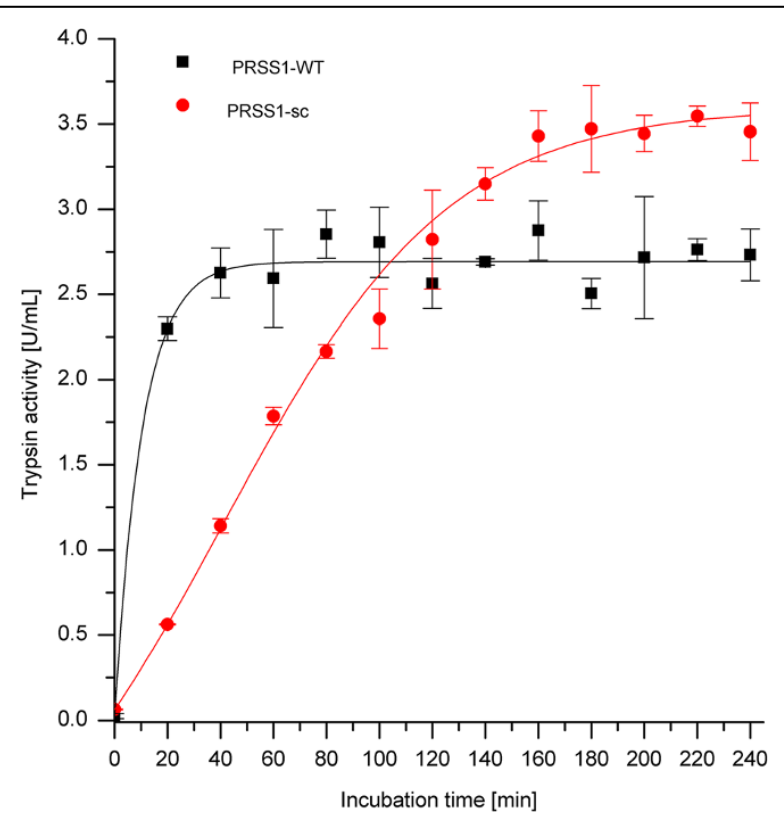

Figure 6 Activation of trypsinogen with human enteropeptidase. Enteropeptidase-mediated trypsinogen activation was measured in $0.1 \mathrm{~mol} / \mathrm{L} \mathrm{Tris-} \mathrm{HCl} \mathrm{pH} 8,1 \mathrm{mmol} / \mathrm{L} \mathrm{CaCl} 2$ at $37^{\circ} \mathrm{C}$ with $2 \mu \mathrm{mol} / \mathrm{L}$ trypsinogen and $\mathrm{hEPI}-\mathrm{Sc}-\mathrm{C} 112 \mathrm{~S}$ ( $1 \mathrm{nmol} / \mathrm{L}$ final concentration). 
Table 1 Kinetic parameters for trypsinogen with substrate Cbz-GPR-pNA

\begin{tabular}{llll}
\hline & $\boldsymbol{K}_{\mathbf{m}}[\boldsymbol{\mu m o l} / \mathbf{L}]$ & $\boldsymbol{k}_{\text {cat }}[\mathbf{1} / \mathbf{s}]$ & $\boldsymbol{k}_{\text {cat }} / \boldsymbol{K}_{\mathbf{m}}[\mathbf{L} / \boldsymbol{\mu m o l} / \mathbf{s}]$ \\
\hline PRSS1-WT & $78.0 \pm 12.2$ & $324.1 \pm 13.8$ & $4.7 \pm 0.5$ \\
PRSS1-SC & $129.8 \pm 8.4$ & $489.0 \pm 18.9$ & $3.7 \pm 0.3$ \\
PRSS1-WT* & $27 \pm 3$ & $99 \pm 5$ & 3.7 \\
\hline
\end{tabular}

*Parameters as given by [31].

\section{Kinetic parameters}

To determine whether the mutations of surface-charged trypsinogen had an influence on the enzyme activity, Michaelis-Menten kinetic parameters were determined. Although the $K_{\mathrm{m}}$ value of the surface-charged trypsinogen was slightly increased compared to wild-type trypsinogen, no major differences for $K_{\mathrm{m}}, k_{\mathrm{cat}}$ or $k_{\mathrm{cat}} / K_{\mathrm{m}}$ values were observed (Table 1, Additional file 2 and Additional file 3). PRSS1-WT had a specific activity of $54.6 \mathrm{U} / \mathrm{mg}$. In comparison, PRSS1-sc had a slightly increased specific activity of $69 \mathrm{U} / \mathrm{mg}$. The catalytic efficiency $\left(k_{\mathrm{cat}} / K_{\mathrm{m}}\right.$ value) showed no difference for wild-type trypsinogen and surface-charged trypsinogen, indicating that the active center of the enzyme was not influenced.

To summarize these results, we found that the directed mutation of the trypsinogen surface charge led to an almost complete loss of trypsinogen autoactivation, while the enzyme could still be completely activated by its natural activation enzyme human enteropeptidase. These results were confirmed by activity measurements and by SDS-PAGE. Although the kinetic parameters of wild-type and surfacecharged human trypsinogen for small peptide substrates were essentially the same, the activation of the surface-charged variant by human enteropeptidase occurred slightly slower than in the case of the wild-type enzyme.

\section{Discussion}

Enzyme autoactivation is a specific type of protein-protein interaction that is not only known to trypsinogen, but also for a number of other enzymes, including proteases such as pepsinogen and prothrombin [3,22-24]. Although different autoactivation mechanisms for the above mentioned enzymes exist, the intermolecular mechanism behind the trypsinogen autoactivation could potentially be a model for investigating the influence of protein surface charges on protein-protein interactions.

In this study, a human trypsinogen mutant was created with a distinct distribution of a surface charge pattern. This idea was based on our finding, that a trypsinogen variant from guinea pig which is defective in autoactivation shows a very specific distribution of surface charges. When we created a human variant in which a similar surface charge distribution was introduced, this led to a mutant of the human trypsinogen that showed a dramatically reduced autoactivation.

Lawrence et al. demonstrated that proteins can be highly supercharged [15] without abolishing their folding or function. Specifically, the net charge of GFP was increased by several amino acid exchanges that led to variants which remained entirely soluble upon thermal and chemical treatment. Supercharging altered the intermolecular properties of the proteins, providing aggregation resistance and the ability to associate in folded form with oppositely charged macromolecules [15]. The supercharging of GFP was quite intense, with an increase of the net charge from -7 to +36 or $-30[15,16]$. In the structure-based design of supercharged, highly thermoresistant antibodies, the best mutant had an increased positive charge by eight [14]. In that study, fewer substitutions in the single-chain variable fragment antibody

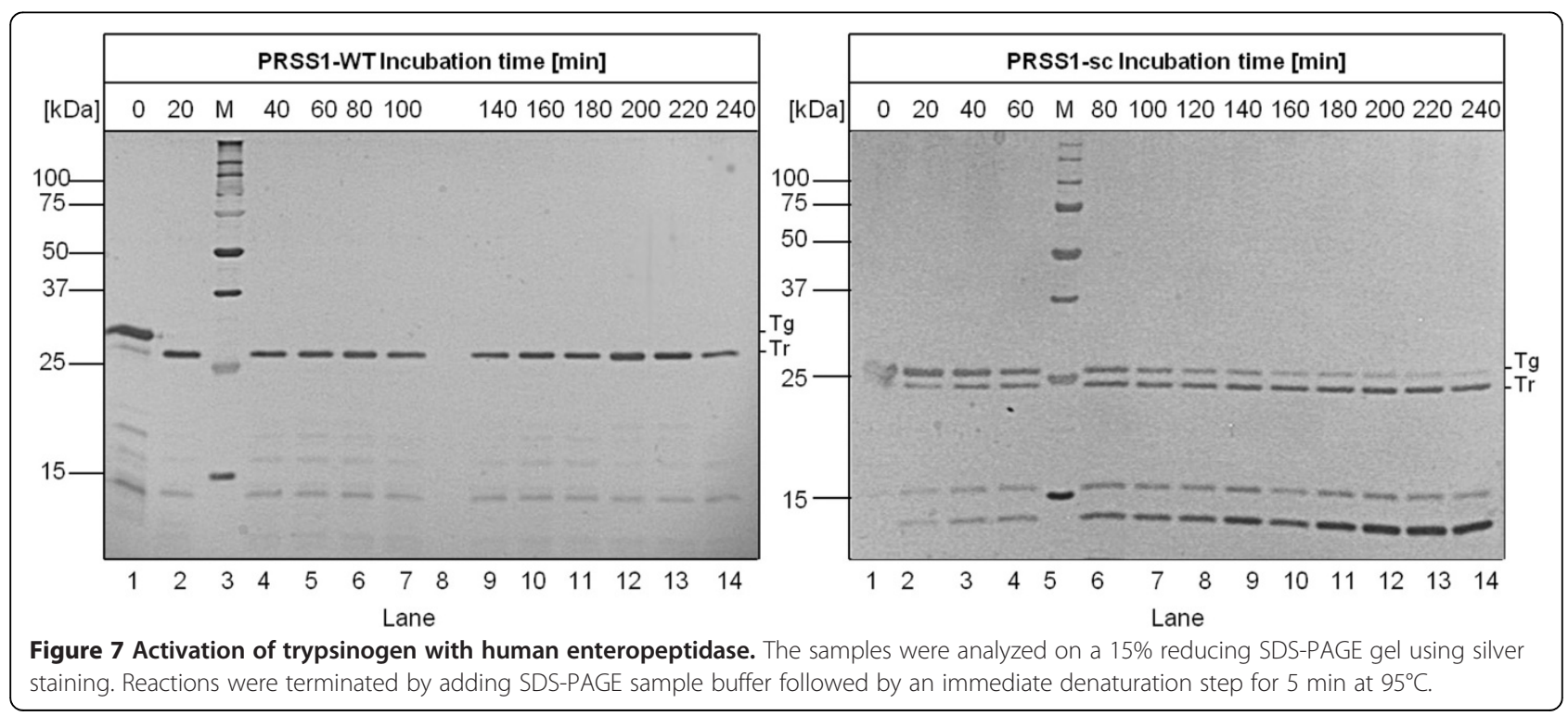


were required to achieve improvements in thermostability and affinity. The method of surface charging was also used by us in an earlier study to improve the solubility and thermostability of human enteropeptidase [17]. In this case, several mutations were introduced that led to six additional negative charges. The increased net charge led to a more than 100-fold higher solubility of the enzyme.

In this study, the surface charge of trypsinogen was changed by mutation of several amino acids, which resulted in a variant with practically no autoactivation.

Numerous amino acid substitutions have been discussed in the literature with respect to their effect on the stability of human trypsin. A mutation that was described in the literature and also examined in this study is located at position Arg122. This position is known to influence the autolytic - not the autoactivation - properties of the enzyme. The autolytic cleavage of the Arg122-Val123 peptide bond was suggested to trigger rapid trypsin degradation by increasing structural flexibility and exposing further tryptic sites [25]. Mutations at position 122, such as exchange to histidine or cysteine, inhibited the autolysis of trypsin [26-28] and enhanced the autoactivation of trypsinogen $[26,28]$. In this study, the mutation R122K did influence the self-cleavage of the enzyme, as shown by the SDSPAGE gels. Furthermore, no decreasing activity was determined during activation with enteropeptideas and no increasing effect on the autoactivation was observed. We assume that the effect of a mutation at position 122 is too weak to cause a significant effect in the context of the surface charging we performed.

In this study, we could also show that the surface charge influences the autoactivation behavior of trypsinogen by investigating this property at different salt concentrations. Based on our results we could conclude that autoactivation is influenced by the surface charge of the protein because the autoactivation is decreased at higher ionic strength conditions.

The net charge of the modified protein was changed from a negative charge $(-2)$ in the wild-type trypsinogen to a positive charge $(+5)$ in the mutant. In total the human surface-charged trypsinogen has 16 negatively charged residues and 21 positively charged residues. More specifically, human wild-type trypsinogen shows a distinct negative surface potential on one side of the protein (Figure 1). Interestingly, these negative charges are mostly present close to the activation sequence of the protein. We therefore hypothesize that the negatively charged domains in the human wild-type trypsinogen allow an interaction with the positively charged surface areas of another trypsinogen molecule, and that this interaction leads to the autoactivation of the enzyme. While this study does not prove that the wild-type autoactivation mechanism is directly controlled by the surface charge of the protein and combinatorial effects may apply, it is nevertheless clear that a modified surface charge strongly affects the autoactivation behavior. At the same time, enteropeptidase can still activate the modified trypsinogen with an only moderately reduced efficiency, indicating that the interaction of these two proteins is determined by a different pattern of electrostatic interactions.

Additionally, it is also possible that reduced autoactivation of surface-charged trypsinogen is based on other effects like post-translational modifications, higher stability of the enzyme and/or conformational changes. As already stated, the advantage of a rational protein design is that the mutations on protein surface are less likely to significantly affect the core structure and therefore the function of the protein [13]. Trypsinogen mutant was designed by reducing possibility of post-translational modifications and we could also show that the catalytic efficiency has not changed. We also could show that autoactivation of wild-type trypsinogen is decreased at higher ionic strength (Figure 5). This proves that the modified surface charge of the protein can not only control protein-protein interactions in general, but also selectively, as in case of our model enzyme trypsinogen. This selective influence of a protein surface charge on its interaction with other proteins has not been demonstrated by us or, to the best of our knowledge, by anybody else until now.

\section{Conclusion}

In this study, we were able to reduce the autoactivation of human trypsinogen by the modification of its protein surface charge. The mutation of ten amino acids led to an increase in the net charge of the enzyme and resulted in a reduced autoactivation, which is probably due to specifically disturbed protein-protein interactions between two trypsin(ogen) molecules. The activation of trypsinogen by enteropeptidase was, in contrast, only influenced in a minor way. This gives a strong indication, that the protein surface charge of trypsinogen has a specific regulatory function on the protein-protein interaction pattern of the enzyme.

\section{Methods \\ Materials}

Ecotin was expressed in E. coli BL21 as described by Pál et al., $1996[29,30]$ and purified via a trypsin affinity column. Purified ecotin was coupled to a pre-packed NHSactivated Sepharose column (GE Healthcare) according to the manufacturer's protocol.

Host strains E. coli DH5 $\alpha$, E. coli BL21 (DE3) and plasmid pET28a $(+)$ were from Novagen (Darmstadt, Germany). N-Cbz-Gly-Pro-Arg- $p$-nitroaniline was purchased from Bachem AG (Bubendorf, Switzerland). Human enteropeptidase hEPL-Sc-C112S was prepared 
according to Simeonov et al., 2010 [17]. Chemicals were of the highest purity available.

\section{Construct human trypsinogen mutant}

Full-length cDNA of PRSS1 (human cationic trypsinogen) was from Deutsches Ressourcenzentrum für Genomforschung $\mathrm{GmbH}$ (Berlin, Germany). The plasmid (PRSS1 $\mathrm{N}-2 \mathrm{X}$ in vector full ORF shuttle clone IOH 43660) contained the full-length cDNA of PRSS1 [GenBank: NM_002769.4] and a stop codon.

The gene was amplified via polymerase chain reaction (PCR) using the forward primer 5'-ggagatataccatgggcttt gatgatgatgacaag-3' and the reverse primer 5 '-cttgtcatcat catcaaagcccatggtatatctcc-3' resulting in the $\mathrm{N}$-terminal end of the protein Met-Gly-Phe-Asp ${ }_{4}$-Lys. It was shown that the modification of the N-terminus of trypsinogen enhances the expression level [31]. For the reason in the present study the N-terminus was also changed to MetGly-Phe-Asp 4 -Lys.

The PCR was performed by heating for $2 \mathrm{~min}$ at $95^{\circ} \mathrm{C}$, followed by 18 cycles of $95^{\circ} \mathrm{C}$ for $30 \mathrm{~s}, 54^{\circ} \mathrm{C}$ for $1 \mathrm{~min}$, $68^{\circ} \mathrm{C}$ for $1 \mathrm{~min}$ and an additional extension time at $68^{\circ} \mathrm{C}$ for $2 \mathrm{~min}$. The amplified PCR product was analyzed via a $1 \%$ agarose gel and purified via a gel extraction kit (Qiagen, Hilden, Germany). The purified DNA sequence was cloned into the pET28a vector via restriction sites NcoI and XhoI. E. coli BL21 (DE3) was transformed with construct pET28a-PRSS1dAP.

The DNA of the surface-charged trypsinogen was obtained via gene synthesis (Eurofins MWG Operon, Ebersberg, Germany). The N-terminal end was modified as described above for wild-type trypsinogen.

\section{Expression and purification of human trypsinogen}

Trypsinogen was expressed as inclusion bodies in E. coli cells. E. coli BL21 (DE3) cells harboring the expression vector with the PRSS1 gene were grown in TB medium with $30 \mu \mathrm{g} / \mathrm{mL}$ kanamycin at $37^{\circ} \mathrm{C}$ until an $\mathrm{OD}_{600}$ of 0.8 to 1 was reached. The expression was induced by adding $1 \mathrm{mmol} / \mathrm{L}$ IPTG and glucose to a final concentration of $1 \%(\mathrm{w} / \mathrm{v})$. The cells were incubated for $18 \mathrm{~h}$ at $25^{\circ} \mathrm{C}$ and then harvested by centrifugation ( $20 \mathrm{~min}, 5000 \mathrm{~g}$ ).

Inclusion bodies were purified by resuspending the cell pellet in $100 \mathrm{mmol} / \mathrm{L}$ Tris- $\mathrm{HCl}(\mathrm{pH}$ 7.0) $1 \mathrm{mmol} / \mathrm{L}$ EDTA and $3 \mathrm{mmol} / \mathrm{L} \mathrm{MgCl}_{2}$ containing $0.1 \mathrm{mg} / \mathrm{mL}$ lysozyme and $10 \mu \mathrm{g} / \mathrm{mL}$ DNase I. The cells were disrupted with a high-pressure homogenizer (two passages of 1000 bar). After incubation for $30 \mathrm{~min}$ at $24^{\circ} \mathrm{C}$, disrupted cells were centrifuged $\left(20000 \mathrm{~g}, 4^{\circ} \mathrm{C}, 30 \mathrm{~min}\right)$.

The inclusion bodies comprising the trypsinogen were prepared from the insoluble fraction after the cell disruption as follows: inclusion bodies were resuspended in IB washing buffer I ( $20 \mathrm{mmol} / \mathrm{L}$ EDTA $\mathrm{pH} 8.0,500 \mathrm{mmol} / \mathrm{L}$ $\mathrm{NaCl}, 2 \%$ Triton $\mathrm{X}-100$ ), stirred for $30 \mathrm{~min}$ at room temperature and centrifuged for $30 \mathrm{~min}$ at $20000 \mathrm{~g}$. The resulting pellet was washed again with IB washing buffer I and twice with IB washing buffer II $(20 \mathrm{mmol} / \mathrm{L}$ EDTA, $100 \mathrm{mmol} / \mathrm{L}$ Tris-HCl, $\mathrm{pH}$ 7.0).

$1 \mathrm{~g}$ of inclusion bodies were solubilized in $20 \mathrm{~mL} 4 \mathrm{~mol} / \mathrm{L}$ Gnd-HCl, $0.1 \mathrm{~mol} / \mathrm{L}$ Tris- $\mathrm{HCl} \mathrm{pH} \mathrm{8.0,} 5 \mathrm{mmol} / \mathrm{L}$ EDTA, and then reduced with DTT (final concentration $30 \mathrm{mmol} / \mathrm{L}$ ) for $20 \mathrm{~min}$ at $60^{\circ} \mathrm{C}$. Afterwards, DTT was removed via a desalting column (GE Healthcare). The refolding was done via fast dilution of protein (final concentration $100 \mu \mathrm{g} / \mathrm{mL}$ ) in $0.7 \mathrm{~mol} / \mathrm{L} \mathrm{Arg-HCl} \mathrm{(pH} \mathrm{8.6),} 1 \mathrm{mmol} / \mathrm{L}$ EDTA, $2 \mathrm{mmol} /$ $\mathrm{L}$ reduced glutathione and $2 \mathrm{mmol} / \mathrm{L}$ oxidized glutathione. The refolding mixture was incubated for $16 \mathrm{~h}$ at $4^{\circ} \mathrm{C}$. The refolded trypsinogen was subsequently purified via an ecotin affinity column.

Protein concentrations of trypsinogen were determined spectrophotometrically at $280 \mathrm{~nm}$ using an extinction coefficient of $37525 \mathrm{~L} / \mathrm{mol} / \mathrm{cm}$ for PRSS1-WT [calculated by Protparam from http://www.expasy.org/].

\section{Trypsin activity assay}

Trypsin activity was determined using the synthetic substrate $\mathrm{N}$-Cbz-Gly-Pro-Arg- $p$-nitroaniline (final concentration $200 \mu \mathrm{mol} / \mathrm{L}$ ) with an absorption readout at $405 \mathrm{~nm}$ in $0.1 \mathrm{~mol} / \mathrm{L} \mathrm{Tris-} \mathrm{HCl}(\mathrm{pH} 8.0) 1 \mathrm{mmol} / \mathrm{L} \mathrm{CaCl}_{2}$ at $25^{\circ} \mathrm{C}$.

\section{Activation of trypsinogen by enteropeptidase}

Trypsinogen $(2 \mu \mathrm{mol} / \mathrm{L}$ final concentration) was activated by human enteropeptidase hEPl-Sc-C112S $(1 \mathrm{nmol} / \mathrm{L}$ final concentration) in $0.1 \mathrm{~mol} / \mathrm{L}$ Tris- $\mathrm{HCl}(\mathrm{pH} 8.0) 1 \mathrm{mmol} / \mathrm{L}$ $\mathrm{CaCl}_{2}$ at $37^{\circ} \mathrm{C}$. At given times, aliquots for the trypsin activity assay and SDS-PAGE analysis were taken.

The activation rate constant was calculated for wild-type and surface charged trypsinogen based on the linear slope of the increasing trypsin activity. Together with the specific activity we then calculated how many trypsinogen molecules are activated by trypsin per minute.

\section{Autoactivation of trypsinogen}

Trypsinogen in $50 \mathrm{mmol} / \mathrm{L} \mathrm{HCl}$ was diluted to a $2 \mu \mathrm{mol} / \mathrm{L}$ final concentration in $0.1 \mathrm{~mol} / \mathrm{L}$ Tris- $\mathrm{HCl} \mathrm{pH} 8.0$ in the presence of $1 \mathrm{mmol} / \mathrm{L} \mathrm{CaCl}_{2}$. Autoactivation was initiated by addition of $10 \mathrm{nmol} / \mathrm{L}$ bovine trypsin and the reaction mixture was incubated at $37^{\circ} \mathrm{C}$. At given times, aliquots for the trypsin activity assay and SDS-PAGE analysis were taken.

\section{SDS-PAGE}

Autoactivation of trypsinogen was also visualized by gel electrophoresis and silver staining. Samples were heat denatured at $95^{\circ} \mathrm{C}$ for $5 \mathrm{~min}$ and loaded onto $15 \%$ mini-gels (Miniprotean; Bio-Rad Laboratories, Hercules, CA, USA). Silver staining was performed according to Shevchenko et al., 1996 [32]. 


\section{Modeling}

Models for the structure of guinea pig trypsinogen and human trypsinogen were generated with the program MODELLER using the bovine trypsinogen structure [PDB: $1 T G N]$ as template [33]. The atomic coordinates of the structures were obtained from the Protein Databank at the RCSB [http://www.rcsb.org/pdb/home/home.do]. The model with the lowest DOPE score [34] obtained from MODELLER was refined with fragment-guided MD simulation (FG-MD) [http://zhanglab.ccmb.med.umich.edu/ FG-MD/] [35].

The program Coot was used for modeling of mutations in the human trypsin structure [36]. For visualization of the protein structure and the surface potential PyMol was used [37]. The surface potential was calculated by PDB2PQR [38,39].

\section{Additional files}

Additional file 1: Autoactivation of wild-type and E79K trypsinogen at $\mathrm{pH}$ 8. Trypsinogen autoactivation was measured in $100 \mathrm{mmol} / \mathrm{L}$ Tris- $\mathrm{HCl} \mathrm{pH} 8,1 \mathrm{mmol} / \mathrm{L} \mathrm{CaCl}_{2}$ at $37^{\circ} \mathrm{C}$ with $2 \mu \mathrm{mol} / \mathrm{L}$ trypsinogen and $1 \mathrm{nmol} / \mathrm{L}$ or $10 \mathrm{nmol} / \mathrm{L}$ trypsin as an initial starting concentration. Trypsin activity was determined with CBZ-GPR-pNA as substrate.

Additional file 2: Kinetic analysis of PRSS1-WT. Kinetic parameters are given in Table 1. Enzyme was activated by human enteropeptidase (hEPI-Sc-C112S) for $200 \mathrm{~min}$ at $37^{\circ} \mathrm{C}$ in $100 \mathrm{mmol} / \mathrm{L}$ Tris- $\mathrm{HCl} \mathrm{pH}$ 8.0, $1 \mathrm{mmol} / \mathrm{L} \mathrm{CaCl}_{2}$. Assays were performed in $100 \mathrm{mmol} / \mathrm{L}$ Tris- $\mathrm{HCl} \mathrm{pH}$ 8.0, $1 \mathrm{mmol} / \mathrm{L} \mathrm{CaCl}$, and $10 \mu \mathrm{mol} / \mathrm{L}$ to $1000 \mu \mathrm{mol} / \mathrm{L}$ CBZ-GPR-pNA at room temperature. The reaction was started by adding PRSS1 variants $(12.5 \mathrm{ng})$ and monitored continuously for 5 min by an absorbance measurement at $405 \mathrm{~nm}$ (extinction coefficient for p-nitroaniline $\varepsilon=10092 \mathrm{~L} / \mathrm{mol} / \mathrm{cm}$ ).

Additional file 3: Kinetic analysis of PRSS1-sc. Kinetic parameters are given in Table 1. Enzyme was activated by human enteropeptidase (hEPI-Sc-C112S) for $200 \mathrm{~min}$ at $37^{\circ} \mathrm{C}$ in $100 \mathrm{mmol} / \mathrm{L}$ Tris-HCl pH 8.0,

$1 \mathrm{mmol} / \mathrm{L} \mathrm{CaCl}$. Assays were performed in $100 \mathrm{mmol} / \mathrm{L}$ Tris- $\mathrm{HCl} \mathrm{pH}$ 8.0, $1 \mathrm{mmol} / \mathrm{L} \mathrm{CaCl}$ and $10 \mu \mathrm{mol} / \mathrm{L}$ to $1000 \mu \mathrm{mol} / \mathrm{L}$ CBZ-GPR-pNA at room temperature. The reaction was started by adding PRSS1 variants (12.5 ng) and monitored continuously for 5 min by an absorbance measurement at $405 \mathrm{~nm}$ (extinction coefficient for p-nitroaniline $\varepsilon=10092 \mathrm{~L} / \mathrm{mol} / \mathrm{cm}$ ).

\section{Competing interests}

A european patent application about the surface-charged human trypsinogen mutant was filed (EP13187194).

\section{Authors' contributions}

KB designed and performed the experiments and wrote the manuscript. TK helped with the discussion and wrote the manuscript. NS helped with protein modeling and wrote the manuscript. TZ helped with design of all experiments and wrote the manuscript. All authors corrected the manuscript. All authors read and approved the final manuscript.

\section{Acknowledgements}

We gratefully acknowledge Stefanie Langanke for the expert technical assistance, Renato Weiße for his support with modeling trypsinogen structures and Dr. Andrew Hagan for proofreading. This work was supported by the Federal Ministry of Education and Research (BMBF) Go-Bio project no. 0315988 to TZ.

Received: 20 August 2014 Accepted: 11 December 2014

Published online: 28 December 2014

\section{References}

1. Gitlin I, Carbeck JD, Whitesides GM: Why are proteins charged? Networks of charge-charge interactions in proteins measured by charge ladders and capillary electrophoresis. Angew Chem Int Ed Engl 2006, 45:3022-3060

2. Whitcomb D, Lowe M: Human pancreatic digestive enzymes. Dig Dis Sci 2007, 52:1-17

3. Kay J, Kassell B: The autoactivation of trypsinogen. J Biol Chem 1971, 246:6661-6665.

4. Sahin-Tóth M: Biochemical models of hereditary pancreatitis. Endocrinol Metab Clin North Am 2006, 35:303-312.

5. Teich N, Rosendahl J, Tóth M, Mössner J, Sahin-Tóth M: Mutations of human cationic trypsinogen (PRSS1) and chronic pancreatitis. Hum Mutat 2006, 27:721-730.

6. Kiraly O, Guan L, Szepessy E, Toth M, Kukor Z, Sahin-Toth M: Expression of human cationic trypsinogen with an authentic $\mathrm{N}$ terminus using intein-mediated splicing in aminopeptidase P deficient Escherichia coli. Protein Expres Purif 2006, 48:104-111.

7. Nemoda Z, Sahin-Tóth M: The tetra-aspartate motif in the activation peptide of human cationic trypsinogen is essential for autoactivation control but not for enteropeptidase recognition. J Biol Chem 2005, 280:29645-29652.

8. Ózsvári B, Hegyi P, Sahin-Tóth M: The Guinea Pig Pancreas Secretes a Single Trypsinogen Isoform, Which is defective in autoactivation. Pancreas 2008, 37(2):182-188.

9. Pasternak A, Liu X, Lin T, Hedstrom L: Activating a zymogen without proteolytic processing: mutation of Lys 15 and Asn194 activates trypsinogent. Biochemistry 1998, 37:16201-16210.

10. Broderick JW, LARGMAN C, JOHNSON JH, GEOKAS MC: Human cationic trypsinogen. Purification, characterization, and characteristics of autoactivation. J Biol Chem 1978, 253:2732-2736.

11. Teich N, Le Maréchal C, Kukor Z, Caca K, Witzigmann H, Chen J, Tóth M, Mössner J, Keim V, Férec C, Sahin-Tóth M: Interaction between trypsinogen isoforms in genetically determined pancreatitis: mutation E79K in cationic trypsin (PRSS1) causes increased transactivation of anionic trypsinogen (PRSS2). Hum Mutat 2004, 23:22-31.

12. Strickler SS, Gribenko AV, Gribenko AV, Keiffer TR, Tomlinson J, Reihle T, Loladze W, Makhatadze Gl: Protein stability and surface electrostatics: a charged relationship. Biochemistry 2006, 45:2761-2766.

13. Sanchez-Ruiz JM, Makhatadze Gl: To charge or not to charge? Trends Biotechnol 2001, 19:132-135.

14. Miklos AE, Kluwe C, Der BS, Pai S, Sircar A, Hughes RA, Berrondo M, Xu J, Codrea V, Buckley PE, Calm AM, Welsh HS, Warner CR, Zacharko MA, Carney JP, Gray JJ, Georgiou G, Kuhlman B, Ellington AD: Structure-based design of supercharged, highly thermoresistant antibodies. Chem Biol 2012, 19:449-455.

15. Lawrence MS, Phillips KJ, Liu DR: Supercharging proteins can impart unusual resilience.J Am Chem Soc 2007, 129:10110-10112.

16. McNaughton BR, Cronican JJ, Thompson DB, Liu DR: Mammalian cell penetration, siRNA transfection, and DNA transfection by supercharged proteins. Proc Natl Acad Sci U S A 2009, 106:6111-6116.

17. Simeonov P, Berger-Hoffmann R, Hoffmann R, Sträter N, Zuchner T: Surface supercharged human enteropeptidase light chain shows improved solubility and refolding yield. Protein Eng Des Sel 2011, 24:261-268.

18. Gaboriaud C, Serre L, Guy-Crotte O, Forest E, Fontecilla-Camps JC: Crystal structure of human trypsin 1: unexpected phosphorylation of Tyr151. J Mol Biol 1996, 259:995-1010.

19. Sahin-Tóth $M$, Kukor Z, Nemoda Z: Human cationic trypsinogen is sulfated on Tyr154. FEBS J 2006, 273:5044-5050.

20. Sahin-Toth M, Gráf L, Tóth M: Trypsinogen stabilization by mutation Arg117 $\rightarrow$ His: a unifying pathomechanism for hereditary pancreatitis? Biochem Biophys Res Commun 1999, 264:505-508.

21. Kukor Z, Toth M, Pal G, Sahin-Toth M: Human cationic trypsinogen - Arg (117) is the reactive site of an inhibitory surface loop that controls spontaneous zymogen activation. J Biol Chem 2002, 277:6111-6117.

22. Bustin M, Conway-Jacobs A: Intramolecular activation of porcine pepsinogen. J Biol Chem 1971, 246:615-620.

23. al-Janabi J, Hartsuck JA, Tang J: Kinetics and mechanism of pepsinogen activation. J Biol Chem 1972, 247:4628-4632.

24. Barranco-Medina S, Pozzi N, Vogt AD, Di Cera E: Histone H4 promotes prothrombin autoactivation. J Biol Chem 2013, 288:35749-35757. 
25. Várallyay É, Pál G, Patthy A, Szilágyi L, Gráf L: Two mutations in Rat trypsin confer resistance against autolysis. Biochem Biophys Res Commun 1998, 243:56-60.

26. Sahin-Toth $M$, Toth $M$ : Gain-of-function mutations associated with hereditary pancreatitis enhance autoactivation of human cationic trypsinogen. Biochem Bioph Res Co 2000, 278:286-289.

27. Sahin-Toth M: The pathobiochemistry of hereditary pancreatitis: studies on recombinant human cationic trypsinogen. Pancreatology 2001, 1:461-465.

28. Simon P, Weiss FU, Sahin-Toth M, Parry M, Nayler O, Lenfers B, Schnekenburger J, Mayerle J, Domschke W, Lerch MM: Hereditary pancreatitis caused by a novel PRSS1 mutation (Arg-122 - Cys) that alters autoactivation and autodegradation of cationic trypsinogen. J Biol Chem 2002, 277:5404-5410.

29. Pál G, Sprengel G, Patthy A, Gráf L: Alteration of the specificity of ecotin, an E. coli serine proteinase inhibitor, by site directed mutagenesis. FEBS Lett 1994, 342:57-60.

30. Pál G, Szilágyi L, Gráf L: Stable monomeric form of an originally dimeric serine proteinase inhibitor, ecotin, was constructed via site directed mutagenesis. FEBS Lett 1996, 385:165-170.

31. Sahin-Toth M: Human cationic trypsinogen - Role of Asn-21 in zymogen activation and implications in hereditary pancreatitis. J Biol Chem 2000, 275:22750-22755.

32. Shevchenko A, Wilm M, Vorm O, Mann M: Mass spectrometric sequencing of proteins silver-stained polyacrylamide gels. Anal Chem 1996, 68:850-858

33. Eswar N, Webb B, Marti-Renom MA, Madhusudhan MS, Eramian D, Shen M Pieper U, Sali A: Comparative protein structure modeling using Modeller. Curr Protoc Bioinformatics 2006, 5:Unit 5.6.

34. Shen M, Sali A: Statistical potential for assessment and prediction of protein structures.Protein Sci 2006, 15:2507-2524.

35. Zhang J, Liang Y, Zhang Y: Atomic-level protein structure refinement using fragment-guided molecular dynamics conformation sampling. Structure 2011, 19:1784-1795.

36. Emsley P, Lohkamp B, Scott WG, Cowtan K: Features and development of Coot. Acta Crystallogr D Biol Crystallogr 2010, 66:486-501.

37. Schrödinger LL: The PyMOL Molecular Graphics System, Version 1.3r1. 2010

38. Dolinsky TJ, Czodrowski P, Li H, Nielsen JE, Jensen JH, Klebe G, Baker NA: PDB2PQR: expanding and upgrading automated preparation of biomolecular structures for molecular simulations. Nucleic Acids Res 2007, 35:W522-W525.

39. Dolinsky TJ, Nielsen JE, McCammon JA, Baker NA: PDB2PQR: an automated pipeline for the setup of Poisson-Boltzmann electrostatics calculations. Nucleic Acids Res 2004, 32:W665-W667.

\section{Submit your next manuscript to BioMed Central and take full advantage of:}

- Convenient online submission

- Thorough peer review

- No space constraints or color figure charges

- Immediate publication on acceptance

- Inclusion in PubMed, CAS, Scopus and Google Scholar

- Research which is freely available for redistribution 